\title{
Investigating the Prevalence of Intestinal Parasites in Immunocompromised Patients in Bushehr Province, Southwest Iran: A Conventional and Molecular Study
}

\author{
Iran'in Güneybatısindaki Bushehr Eyaletindeki Immün Yetmezliği \\ Olan Hastalarda Bağırsak Parazitlerinin Prevalansının Araştırılması: \\ Konvansiyonel ve Moleküler Bir Çalışma
}
(1) Ali Heydari ${ }^{1}$, (1) Gholamreza Hatam ${ }^{1}$, (1) Moradali Fouladvand ${ }^{2}$, (1) Seyed Mahmoud Sadjjadi ${ }^{1}$, (1) Afshin Barazesh ${ }^{3}$

${ }^{1}$ Shiraz University of Medical Sciences Faculty of Medicine, Department of Parasitology and Mycology, Shiraz, Iran ${ }^{2}$ Bushehr University of Medical Sciences Faculty of Medicine, Department of Microbiology and Parasitology, Bushehr, Iran ${ }^{3}$ Bushehr University of Medical Sciences, The Persian Gulf Marine Biotechnology Research Center, The Persian Gulf Biomedical Sciences Research Institute, Bushehr, Iran

Cite this article as: Heydari A, Hatam G, Fouladvand M, Sadjjadi SM, Barazesh A. Investigating the Prevalence of Intestinal Parasites in Immunocompromised Patients in Bushehr Province, Southwest Iran: A Conventional and Molecular Study. Turkiye Parazitol Derg 2021;45(2):121-127.

\begin{abstract}
Objective: The aim of this study was to determine the status of intestinal parasitic infections in immunocompromised patients in Bushehr province, southwest Iran by conventional and molecular methods.

Methods: A total of 201 stool samples were collected from kidney transplant recipients, AIDS patients and patients under chemotherapy. Samples were collected from healthy people as the control group. The specimens were tested using various conventional methods. Polymerase chain reaction (PCR) testing was performed on samples identified as positive for Coccidia by direct microscopic examination.

Results: Approximately $32.45 \%$ were infected with at least one type of intestinal parasite. The highest (46.8\%) and lowest rates of infection (24\%) were observed in AIDS and chemotherapy patients, respectively, while the infection rate of the control group was 16\%. Isospora spp. and Cryptosporidium spp. were observed in all patient groups, and Sarcocystis spp. sporocysts were detected in one of the transplant recipients. All identified coccidia were confirmed by PCR. There was a significant relationship between the rate of intestinal parasite infection and certain variables.

Conclusion: Given the potential risk of certain intestinal parasites in people with immune deficiency, it is recommended that diagnosis of parasitic infections in such patients be based on specific parasitological methods. Thus, it is advisable that physicians refer them to a parasitology laboratory prior to drug administration.

Keywords: Intestinal parasites, immunodeficiency, chemotherapy, Bushehr province, Iran
\end{abstract}

Öz

Amaç: Bu çalışmanın amacı, İran'ın güneybatısındaki Bushehr eyaletindeki immün yetmezlikli hastalarda bağırsak paraziter enfeksiyonlarının durumunu konvansiyonel ve moleküler yöntemlerle belirlemektir.

Yöntemler: Böbrek nakli alıcılarından, AIDS hastalarından ve kemoterapi alan hastalardan olmak üzere toplam 201 dışkı örneği toplandı. Kontrol grubu numuneleri sağliklı insanlardan toplandı. Numuneler çeşitli konvansiyonel yöntemler kullanılarak test edildi. Polimeraz zincir reaksiyon (PZR) testi, doğrudan mikroskobik incelemelerde tespit edilen pozitif Coccidia örnekleri üzerinde yapildı.

Bulgular: Hastaların yaklaşık \%32,45’i en az bir tür bağırsak paraziti ile enfekte olmuştu. En yüksek $(\% 46,8)$ ve en düşük enfeksiyon oranı (\%24) sırasıly AIDS ve kemoterapi hastalarında görülürken, kontrol grubunun enfeksiyon oranı \%16 idi. 
Isospora spp. ve Cryptosporidium spp. tüm hasta gruplarında ve Sarcocystis spp. sporokistleri ise transplant alıcılarından birinde tespit edildi. Tanımlanan tüm Coccidialar, PZR ile doğrulandı. Bağırsak parazitlerinin oranı ile bazı değişkenler arasında anlamlı bir ilişki mevcuttu.

Sonuç: İmmün yetmezliği olan kiş̧ilerde bazı bağırsak parazitlerinin potansiyel riski göz önüne alındığında, paraziter enfeksiyonların spesifik parazitolojik yöntemlere dayanarak teşhis edilmesi önerilir. Bu nedenle, doktorların ilaç vermeden önce bu hastaları parazitoloji laboratuvarına yönlendirmeleri tavsiye edilir.

Anahtar Kelimeler: Bağırsak parazitleri, immün yetmezlik, kemoterapi, Bushehr eyaleti, İran

\section{INTRODUCTION}

Despite quick advancements in the field of medical sciences and enhancement of health level in most of the world, parasitic diseases are still deemed as the foremost health and economic problems in the world, especially in developing countries. According to a report from World Health Organization, about two-thirds of the world population, namely 3.5 billion people are infected with some types of parasites and about 450 million among them suffer from such diseases with related side-effects every year (1). About 16 million cases of total mortalities that occur annually in developing countries are related to parasitic infections (2). In the meantime, infections caused by intestinal parasites have noticeable position and these infections have spread globally (3). In some cases, intestinal parasitic infections can be very severe and risky, and they may be followed with some complications such as intestinal blockage, appendicitis, cholecystitis, myocarditis, genital infections and extra-intestinal abscesses (4).

Although intestinal parasites are less prevalent in developed countries, patients with immune disorders, malignancies and having organ transplantation are on the rise, which give way to the emergence of opportunistic infections. Therefore, infections due to intestinal parasites are also increasing in developed countries $(5,6)$. The intestinal parasitic infections, particularly opportunistic infections in immunodeficient and patients with cancer, under chemotherapy, radiotherapy, hemodialysis or using corticosteroid drugs, or Acquired Immune Deficiency syndrome (AIDS) patients may be expressed with more intensity and strength and compared to persons with competent immunity they can impose more serious complications to the patient (7-9). One can mainly refer to Coccidia among human parasitic protozoa and to Strongyloides stercoralis as opportunistic parasite among worms that may create mild and self-limiting infections in healthy persons while lifethreatening in patients with immunodeficiency (10-13). Thus, it is highly important to diagnose parasitic infections precisely and timely in these individuals (14).

In a study that was carried out to determine sero-prevalence of Strongyloides stercoralis in patients as users of immun suppressant drugs in Bushehr city (Iran), among total 214 studied patients, 7 cases were reported positively in terms of IgG antibodies against this parasite (15). Similarly, another survey was done on hemodialysis patients in terms of prevalence of intestinal parasites in the same zone where $28.4 \%$ of studied cases were infected with at least one species of intestinal parasites and in this study, researchers have recommended to conduct periodic tests during dialysis and before renal transplant operation as some part of health requirements and related cares in these patients (16). Whereas rate of prevalence of intestinal parasitic infections is especially important in human immunodeficiency virus (HIV) patients, thus it is required for physician to refer the patient to lab in terms of intestinal parasitic infections before administration of various drugs that can affect efficiency of immune system in these patients $(17,18)$. Using various diagnostic methods, the current study analyzes intestinal parasitic infections in three groups of individuals including patients with malignancy and under chemotherapy, renal transplant recipients and AIDS patients.

\section{METHODS}

\section{Ethical Approval and Informed Consent}

This study was approved in research committee of Shiraz University with ethics code 94-7496. Informed consent was obtained from the patients and in the case of minors, from their parents and confidentiality of the information was guaranteed.

\section{Study Location}

Bushehr province is located at southwestern side of Iran. Provincial population is about one million and geographic situation of this city is placed among 27', 19" through 30', 16" of northern latitude and 50', 1" through 52', 59" of eastern longitude with annual average temperature $25.7^{\circ} \mathrm{C}$. The climate of this province includes 7 hot months, 2 temperate to cold months and 3 temperate to hot months over a year (Figure 1).
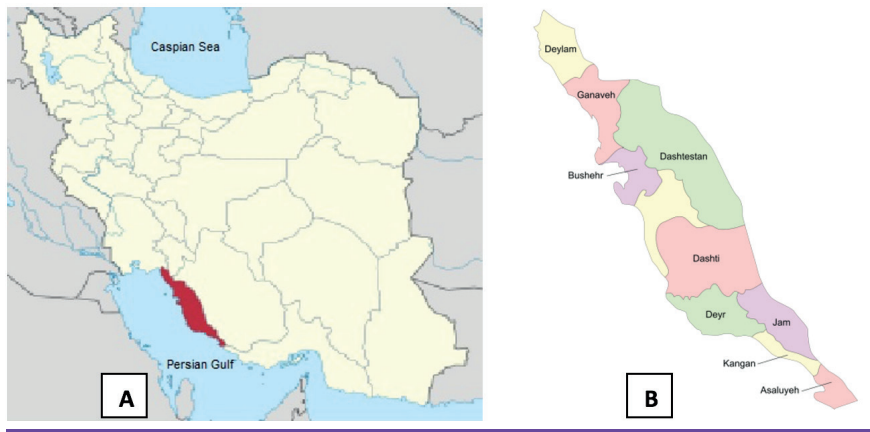

Figure 1. A) Geographical location of Bushehr province (red region). B) Bushehr province map by cities

\section{Collection of Samples}

Bushehr and Dashtestan cities are situated at the center of province, Genaveh locating at north and Kangan at south of the province and they were selected for collection of samples. The study population comprised of 47 AIDS patients, 50 recipients of renal transplantation and 54 patients with cancer who were under chemotherapy. These individuals were sampled within time intervals (2013-2014). Likewise, to compare and interpret the results logically, 50 healthy persons, who were evaluated by direct smear and Formalin- ether concentration techniques to confirm their healthy status, were also elected as control group. To assess relationship between demographic indices and symptoms of intestinal parasitic diseases with parasitic infection in studied patients, a questionnaire was used for the interview with patients. 


\section{Microscopic Techniques}

All 201 collected samples were initially studied using direct method and preparation of wet mount and then by means of Formalin- ether concentration technique. To enhance reliability for precise diagnosis of helminth eggs, Carmine-Alum stain technique was employed and Baermann technique was utilized to diagnose Strongyloides stercoralis larva. To diagnose the cysts and trophozoites of protozoans more accurately, trichrome staining technique was used after wet mount and the modified acid-fast stain technique, which was employed to detect intestinal Coccidia.

\section{Polymerase Chain Reaction (PCR) Tests}

With respect to importance of coccidian infections in HIV patients, all samples, who had been recognized as positive at the first screening phase by means of wet mount and concentration method in terms of intestinal Coccidia, these coccidian positive samples were confirmed by PCR technique, in order to ensure the correctness of the result of the microscopic examination.

DNA samples were extracted using a commercial kit (Yekta Tadjhiz Azma, Iran) according to its manufacturer's protocol, and PCR test was done by means of specific primers Isof and Isor for replication of ribosomal genome of Isospora spp. and two pairs of primers cryf1, Cryf2 and Sarf and Sarr for replication of mitochondria genome (18S rRNA, SSU rRNA) of Cryptosporidium spp. and Sarcocystis spp. respectively.

The specifications of primers as well as used temperature patterns in PCR test are given in Tables 1, 2.

PCR products were treated with electrophoresis on agarose gel (1.5\%) using TAE buffer and ethidium bromide stain and images of the resulting bands were observed and recorded using Gel document Bio-DocmM29 device.

\section{Statistical Analysis}

The results of laboratory tests were statistically analyzed along with questionnaire data by means of statistical SPSS software (IL version 16, SPSS Inc., Chicago) and chi-square test was employed for analysis on relationship between intestinal parasitic infections and clinical symptoms of these infections and some demographic parameters.

\section{RESULTS}

Among total given samples from patients, 49 (32.5\%) were infected with at least one species of intestinal parasites. Infections were most and least common in AIDS patients (46.8\%) and in patients under chemotherapy (24\%), respectively. Of the total population studied, 11 were infected with at least one intestinal Coccidia. The prevalence of infection rate was $16 \%$ in control population (50 members) although there was no significant difference among control group with groups of patients; the infection prevalence was noticeably lower in control group ( $p>0.05$ ). Meanwhile, no positive cases of intestinal Coccidia were seen in control group (Table 3).

The frequency of infection with intestinal parasites in all three studied groups of patients included Giradia intestinalis, Entamoeba coli and Blastocystis spp. were 29.8\%, 29.8\% and $19.95 \%$, respectively and opportunist Coccidia including Cryptosporidium spp., Isospora spp. and Sarcocystis spp. were placed at subsequent positions with frequencies of $16.3 \%, 5.9 \%$ and $2 \%$, respectively (Figures 2, 3).

PCR test was used in order to confirm finally 11 diagnosed coccidian cases by conventional techniques and specific primers (Figure 4).

The results showed that there was significant relationship among symptoms abdominal flatulence, osteoarthritis and abdominal pains and infection, but no significant relationship was visible among variables age, gender and anorexia with infection (Table 4).

\section{DISCUSSION}

Most of intestinal parasitic infections are asymptomatic or appear in mild and self- limiting form in people with healthy and efficient immune system. However, patients with immunodeficiency e.g. patients with cancer who receive chemotherapy, transplanted

\begin{tabular}{|c|c|c|c|c|}
\hline \multirow{2}{*}{ Genus } & \multicolumn{4}{|l|}{ Program } \\
\hline & Processes & Cycles & Temp & Time \\
\hline \multirow{5}{*}{ Sarcocystis } & Denaturation & 1 & $94^{\circ} \mathrm{C}$ & $5 \mathrm{~min}$ \\
\hline & \multirow{3}{*}{ Annealing } & \multirow{3}{*}{30} & $94^{\circ} \mathrm{C}$ & $60 \mathrm{sec}$ \\
\hline & & & $58^{\circ} \mathrm{C}$ & $60 \mathrm{sec}$ \\
\hline & & & $62^{\circ} \mathrm{C}$ & $60 \mathrm{sec}$ \\
\hline & Extension & 1 & $72^{\circ} \mathrm{C}$ & $5 \mathrm{~min}$ \\
\hline \multirow{5}{*}{ Cryptosporidium } & Denaturation & 1 & $94^{\circ} \mathrm{C}$ & $5 \mathrm{~min}$ \\
\hline & \multirow{3}{*}{ Annealing } & \multirow{3}{*}{30} & $94^{\circ} \mathrm{C}$ & $90 \mathrm{sec}$ \\
\hline & & & $58^{\circ} \mathrm{C}$ & $90 \mathrm{sec}$ \\
\hline & & & $62{ }^{\circ} \mathrm{C}$ & $120 \mathrm{sec}$ \\
\hline & Extension & 1 & $72^{\circ} \mathrm{C}$ & $5 \mathrm{~min}$ \\
\hline \multirow{5}{*}{ Isospora } & Denaturation & 1 & $94^{\circ} \mathrm{C}$ & $3 \mathrm{~min}$ \\
\hline & \multirow{3}{*}{ Annealing } & \multirow{3}{*}{45} & $94^{\circ} \mathrm{C}$ & $90 \mathrm{sec}$ \\
\hline & & & $60^{\circ} \mathrm{C}$ & $60 \mathrm{sec}$ \\
\hline & & & $62{ }^{\circ} \mathrm{C}$ & $60 \mathrm{sec}$ \\
\hline & Extention & 1 & $72^{\circ} \mathrm{C}$ & $5 \min$ \\
\hline
\end{tabular}

Table 1. The specific primers used to confirm Coccidia samples detected by conventional methods

\begin{tabular}{|l|l|l|l|}
\hline Genus & Genome & Primers & Sequence \\
\hline \multirow{2}{*}{ Isospora } & \multirow{2}{*}{ Ribosomal } & Isof & 5'-CCGAACGTCATCCGAAATAG-3' \\
\cline { 3 - 4 } & \multirow{2}{*}{ Cryptosporidium } & Isor & 5'-ACTAGGAGCTGACGATACAC-3' \\
\hline \multirow{2}{*}{ Sarcocystis } & SSU rRNA & Cryf1 & 5'-TTCTAGAGCTAATACATGCG-3' \\
\cline { 3 - 4 } & \multirow{2}{*}{ Cryf2 } & 5'-CCATTTCCTTCGAAACAGGA-3' \\
\hline \multirow{2}{*}{ 18S rRNA } & Sarf & 5'-CGTGGTAATTCTATGGCTAATACA-3' \\
\cline { 3 - 4 } & & Sarr & 5'-TTTATGGTTAAGACTACGACGGTA-3' \\
\hline
\end{tabular}


Table 3. Detected intestinal parasites in patients undergoing chemotherapy, AIDS patients, transplant recipients and control group

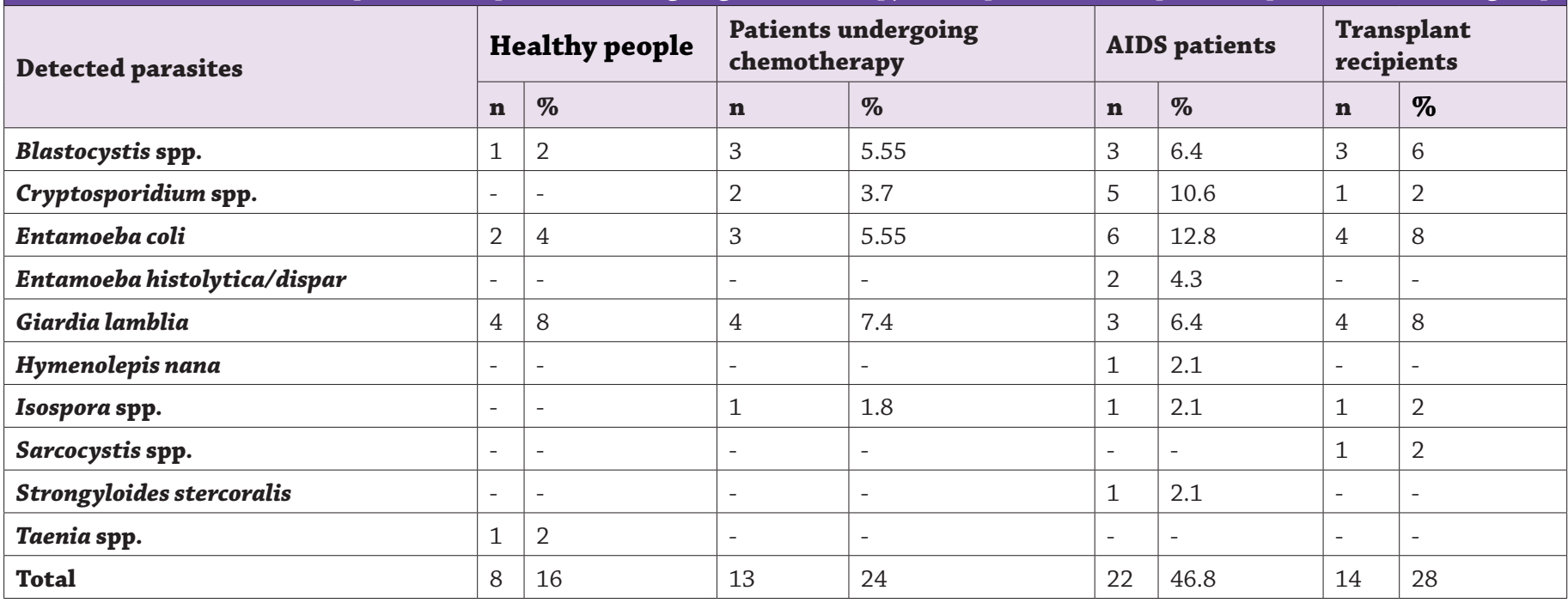
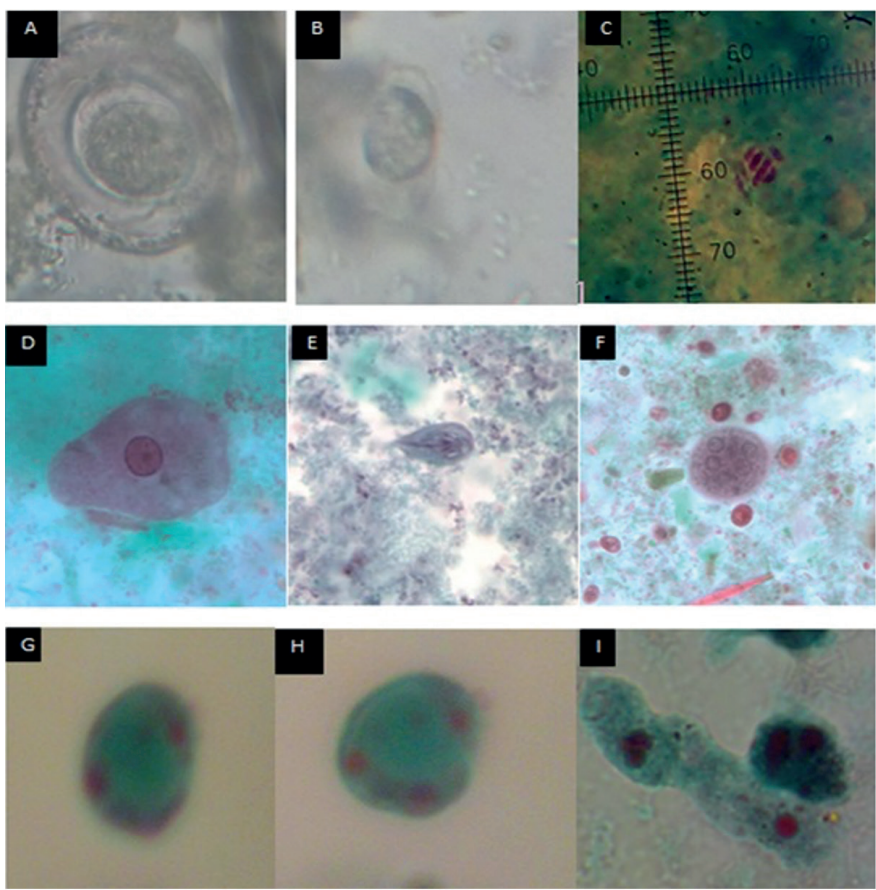

Figure 2. Some parasites identified in the groups studied by conventional methods in different magnifications; A: $H$. nana egg (40X), B: Isospora oocyst (100X), C: Sarcocystis sporocyst (100X), D: E. coli trophosoite (100X), E: G. intestinalis trophosoite (100X), F: E. coli cyst (100X), G\&H: Blastocystis (100X), I: E. histolytica (100X)

organ recipients who receive immunosuppressant drugs and also patients with AIDS are more impaired by them and more complications are imposed to these individuals (7-9). The prevalence of intestinal parasitic infections is usually high in this group of patients and common clinical symptoms are revealed often non-specific and this makes problematic to diagnose infection in these patients. Thus, it seems necessary to detect intestinal parasitic infections with reliance on specific parasitological techniques in this group of patients $(17,18)$.

The prevalence of intestinal parasites was $32.5 \%$ in all three studied groups in this survey. This rate was highest among
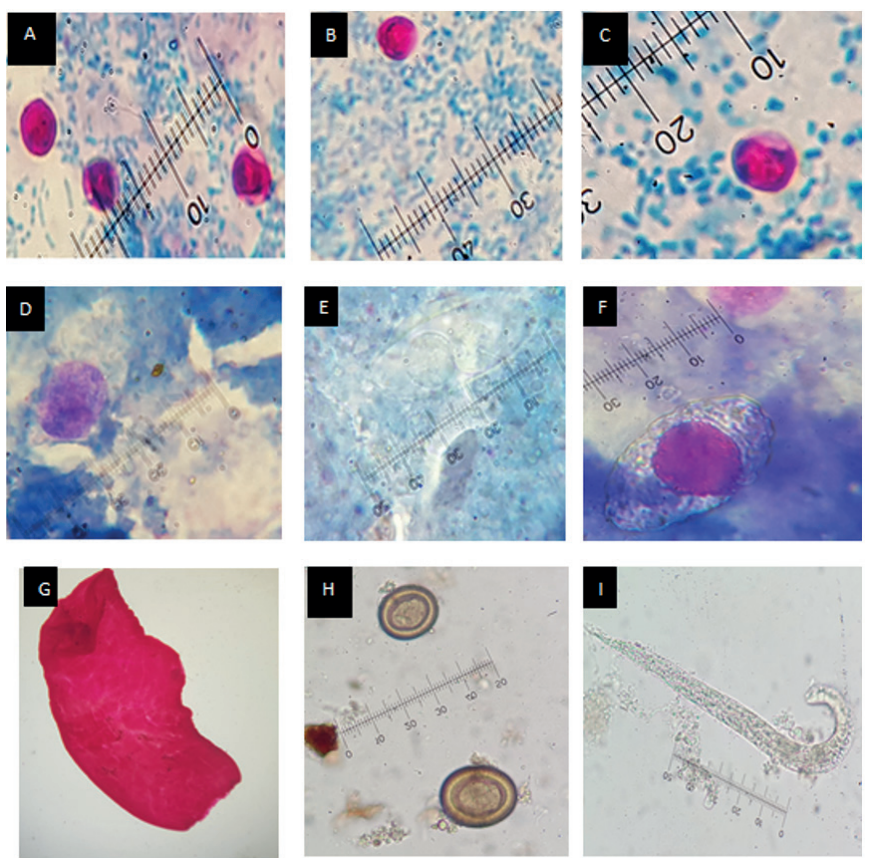

Figure 3. Some parasites identified in the groups studied by conventional methods in different magnifications; $\mathrm{A}-\mathrm{C}$ : Cryptosporidium oocysts (100X), D-F: Isospora oocysts (100X),

G: Taenia spp. proglotid (10X), H: Taenia spp. egg (40X), I: S.stercoralis larvae (40X)

AIDS patients (46.8\%), followed by organ transplantation patients (28\%) and $24 \%$ in group of cancer patients under chemotherapy. Comparison of prevalence rates in three groups of immunodeficiency patients with control group in which the prevalence rate of parasitic infections was $16 \%$ showed that there was noticeable (but statistically not significant) difference among healthy persons and immunodeficiency patients in terms of intestinal parasitic infection and what seems noticeable about presence of intestinal parasitic infection in this group of patients is opportunist nature of some of these parasites and also higher intensity of disease and related complications in these patients. In their survey on dialysis patients, Barazesh et al. (15) have reported a $28.4 \%$ of individuals who were infected at least with 
one species of intestinal parasitic infection and they suggested that dialysis patients testing routinely in terms of presence of intestinal parasitic infections (16). The results of these studies are consistent with the findings resulted from present research. Togeh et al. (16), in their study were examine 261 cancerous patients and under chemotherapy in terms of infection with intestinal parasites and $34 \%$ of them were infected with at least an intestinal parasite and therefore these researchers have declared specific stool exam before starting chemotherapy and during treatment period as basic measures to reduce risk of such parasitic infections (17). In a study done by Athari et al. (18) in Tehran to review prevalence of intestinal parasites in patients as users of immunosuppressive drugs, prevalence of infection was estimated $34.5 \%$ (19).

In a sero-epidemiological study conducted by Fouladvand et al. (14) on cancer patients under chemotherapy and hemodialysis patients in Bushehr city, out of total 214 studied patients, 7 cases $(3.3 \%)$ were diagnosed with positive results for presence of antibody against Strongyloides stercoralis (15). Among 151 sampled patients with immunodeficiency in our study, one case of

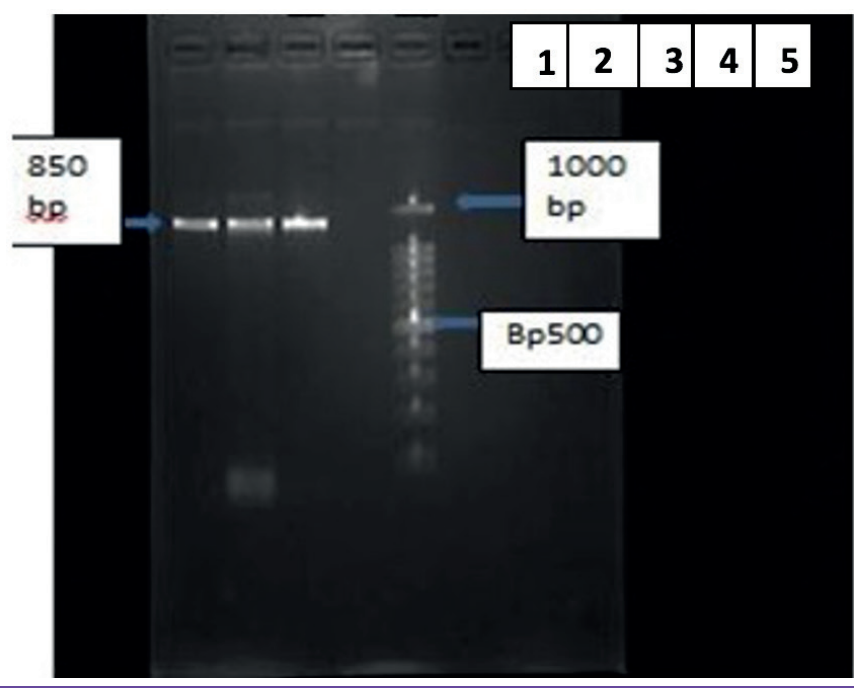

Figure 4. Electrophoresis of PCR products on agarose gel 1.5\%. 1: Cryptosporidium positive control, 2, 3: Cryptosporidium positive samples, 4: Negative control, 5: DNA marker

Table 4. The relationship between parasitic infection and some clinical and demographic variables in studied groups

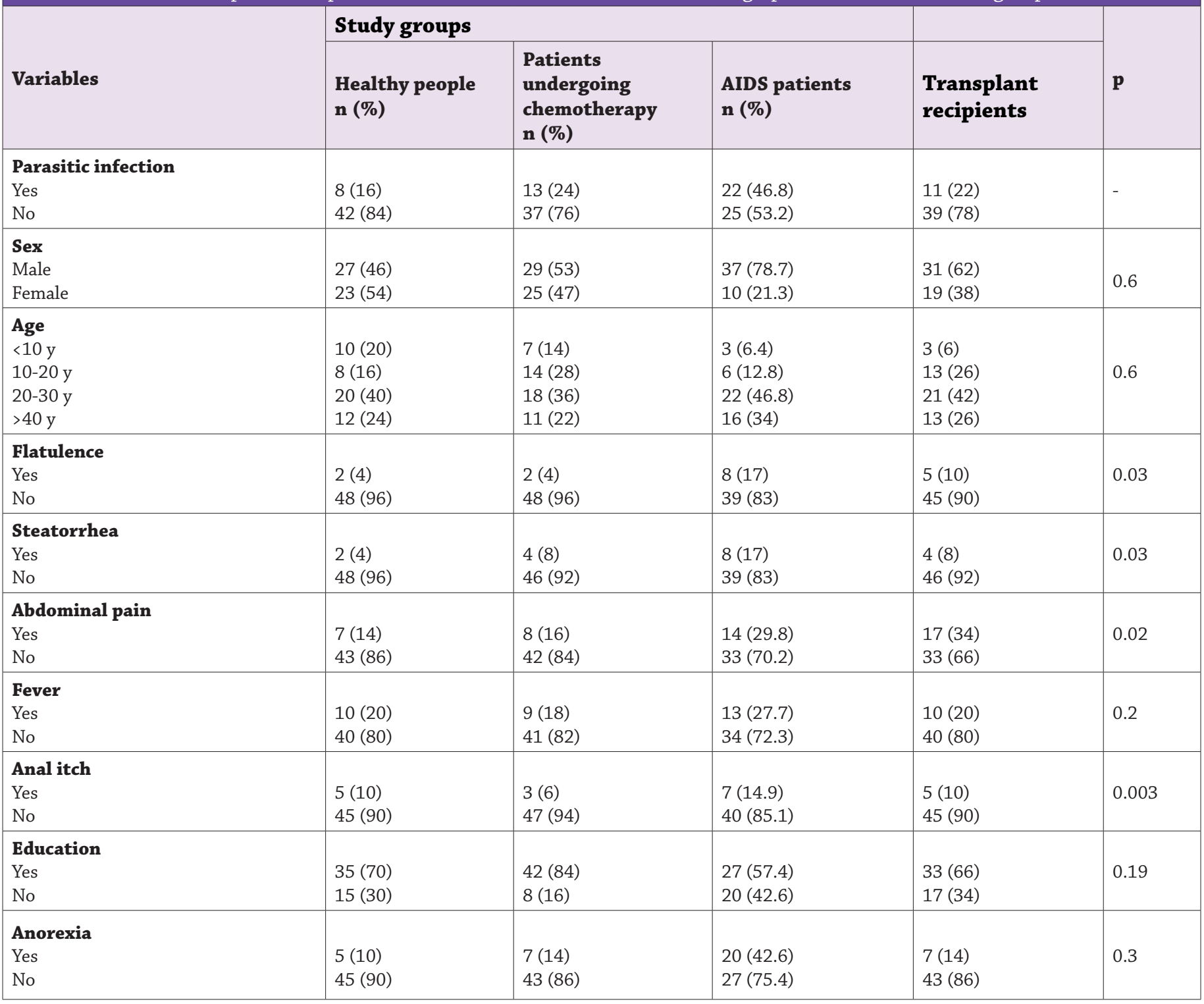


Strongyloides stercoralis larvae was observed in patient with HIV. This indicates $0.6 \%$ prevalence of Strongyloides stercoralis while serological study that conducted one year ago at this region has shown $3.3 \%$ prevalence.

As we know, presence of IgG antibody against Strongyloides stercoralis usually shows infection history and these individuals may not defecate larvae at time of stool exam, because it is unlikely that some patients infected with Strongyloides stercoralis may be at silent phase of diseases upon sampling and excreted larvae may be rare in their stool, therefore they may be reported as negative result in parasitological tests.

Taking corticosteroids in patients, who receive transplanted organ, may converts the chronic form of Strongyloides stercoralis infection into acute syndrome (hyperinfection) (20). Thus, presence of chronic Strongyloides stercoralis in these patients is deemed as a threatening risk factor, because after administration of corticosteroids the disease can appear as hyperinfection form and parasitic larvae disseminated in different tissues of body e.g. liver, lungs, kidneys, central nervous system and heart and it will be followed with mortality of patients (87\%) if not treated timely $(12,13)$. There are several reports about prevalence of intensified Strongyloides stercoralis syndrome in patients with malignancies after treatment with corticosteroid drugs. George Vasquez Rios, reported the asthmatic patient, that exhibited clinical symptoms of pneumonia and chest pain following the administration of corticosteroid and Strongyloides stercoralis larvae has been seen in stool and broncho-alveolar samples, this patient has been cured by administration of Ivermectin (21). Although prevalence of Strogyloides stercoralis hyperinfection and disseminated infection has been reported in various patients as recipients of transplanted organ but morbidity and prevalence of this forms of disease is apparently more visible in renal transplant recipients (2).

Cryptosporidium spp, Isospora spp. and Sarcocystis spp. were observed in all three groups of studied patients while no case of Coccidia was seen in control group. Cryptosporidium spp. is assumed as noticeable warning for the patients with prevalence rates of $7.3 \%, 10.6 \%$ and $2 \%$ in cancer patients, AIDS patients and recipients of transplanted organ, respectively and given that long-term diarrheas with dehydration plus pleural involvement of these patients have been reported; therefore, timely diagnosis and treatment should be addressed in these patients. In a study carried out on 350 immunocompromised patients (Iran, Tehran) prevalence rate of Cryptosporidium spp, and Isospora spp. were $0.3 \%$ and $0.8 \%$ respectively and these two protozoa were the most prevalent intestinal parasites, where these rates are lower than prevalence rate of infection reported in this study (22). Total prevalence of given Coccidia is $16.3 \%$ in our study. With respect to possibility of misdiagnosis of coccidian by microscopic examination, especially the Cryptosporidium spp., confirmation of Cryptosporidium positive samples by molecular methods is necessary as was the case in our study.

Another noticeable point in this study are climatic indicators, Bushehr province is a hot and tropical region and from October to March that are basically assumed as spring season, climatic and geographical factors are more provided for transmission of intestinal parasites. At this season when agricultural and animal-farming activities are done there is more possibility for transferring and dissemination of anthroponotic and zoonotic parasitic infections and among them coccidians, especially the
Cryptosporidium spp. in cows and goats of this region shows higher prevalence and morbidity. In a sero-epidemiological study, Fouladvand et al. (22) estimated the prevalence rate of antibodies against Cryptosporidium spp. $13 \%$ in children under age 5 . This shows prevalence of this Coccidia is higher in normal population of this region, particularly children, and Cryptosporidium spp. is a causing factor in most of long-term diarrheas among children in this season.

Statistical analysis on relationship among infection with intestinal parasites with some variables such as educational level, age and gender and also anorexia did not show significant relationship while significant relationship was observed among infection with these parasites and some variables e.g. abdominal pain, flatulence and osteoarthritis ( $p>0.03$ ). Thus, it is necessary for HIV patients to be under medical care for the onset of some symptom e.g. abdominal pains, flatulence and osteoarthritis and we should consider them as warning symptoms for activation of intestinal parasitic infections in these patients.

\section{CONCLUSION}

With respect to potential risk of this group of infections, especially infection with Strongyloides stercoralis larva and types of opportunist intestinal Coccidia in people with immunodeficiency such as patients under chemotherapy, recipients of transplanted organ and patients with HIV, it is suggested to identify parasitic infections in this group of patients by focusing on specific parasitological methods and before taking any type of medication and intervention measure that can affect efficiency of immune system, physician should refer these patients to lab for diagnosis of intestinal parasites and the needed trainings should be presented to increase their knowledge and to warn about risk of these infections.

\section{ACKNOWLEDGMENTS}

The authors are grateful to the Vice-Chancellor for Research of Shiraz University of Medical Sciences for their financial support.

\section{* Ethics}

Ethics Committee Approval: This study was approved in research committee of Shiraz University of Medical Sciences with Ethics Code IR.SUMS.REC.1394.S128.

Informed Consent: Informed consent was obtained from the patients and in the case of minors, from their parents and confidentiality of the information was guaranteed.

Peer-review: Internally peer-reviewed.

\section{** Authorship Contributions}

Concept: A.H., G.H., M.F., S.M.S., Design: G.H., M.F., Data Collection or Processing: A.H., Analysis or Interpretation: A.H., G.H., M.F., S.M.S., A.B., Literature Search: A.H., G.H., M.F., Writing: A.H., G.H., M.F., S.M.S., A.B.

Conflict of Interest: No conflict of interest was declared by the authors.

Financial Disclosure: This study was financially supported by the Vice-chancellor of Research of Shiraz University of Medical Sciences with grant no. 94.7496. 


\section{REFERENCES}

1. Heravi MM, Rasti S, Vakili Z, Moraveji A, Hosseini F. Prevalence of intestinal parasites infections among Afghan children of primary and junior high schools residing Kashan city, Iran, 2009-2010. Iran J Med Microbiol 2013; 7: 46-52.

2. Davami MH, Rouhi R, Sadeghi AR. The Prevalence of intestinal parasitic infections among 7-15 year old children in Jahrom, Iran during 2006-7. J Jahrom Univ Med Sci 2008; 6: 49-55.

3. Barazesh A, Fouladvand M, Tahmasebi R, Heydari A, Kushesh F. Prevalence of intestinal parasites infection in primary school childen of Bushehr, Iran.Avicenna J Clin Microb Infec 2017; 4: e34335.

4. AthariA, SadafiH, Tokeh GhR. Intestinalparasitesinimmunocompromised patients in Tehran in 1998. J Zanjan Univ Med Sci 2000; 30: 61-8.

5. Emami Naiini A, Shokrian A, ShahrzadSh, Aazami M, Hejazi SH, Tazhibi M. The prevalence of intestinal parasitic and fungal agents in hemodialysis patients in Isfahan. J Isfahan Med Sch 2011; 121: 1655-67.

6. Daryani A, Sarvi S, Aarabi M, Mizani A, Ahmadpour E, Shokri A, et al. Seroprevalence of Toxoplasma gondii in the Iranian general population: a systematic review and meta-analysis. Acta Trop 2014; 137: 185-94.

7. Sarkari B, Shafiei R, Zare M, Sohrabpour S, Kasraian L. Seroprevalence and molecular diagnosis of Toxoplasma gondii infection among blood donors in southern Iran. J Infect Dev Ctries 2014; 8: 543-7.

8. Ahmadpour E, Daryani A, Sharif M, Sarvi S, Aarabi M, Mizani A, et al. Toxoplasmosis in immunocompromised patients in Iran: a systematic review and meta-analysis. J Infect Dev Ctries 2014; 8: 1503-10.

9. Schär F, Trostdorf U, Giardina F, Khieu V, Muth S, Marti H, et al Strongyloides stercoralis: Global Distribution and Risk Factors. PLoS Negl Trop Dis 2013; 7: 2288.

10. Siddiqui AA, Berk SL. Diagnosis of Strongyloides stercoralis infection. Clin Infect Dis 2001; 33: 1040-7.

11. Rouhani S, Mahmoudi M, Kazemi B, Khazan H. Identification of filariform larva (L3) proteins of Strongyloides stercoralis by western blot. Research in Medicine 2007; 31: 311-5.
12. Agrawal V, Agarwal T, Ghoshal UC. Intestinal strongyloidiasis: a diagnosis frequently missed in the tropics. Trans R Soc Trop Med Hyg 2009; 103: 242-6.

13. Vaiyavatjamai P, Boitano JJ, Techasintana P, Tungtrongchitr A. Immunocompromised group differences in the presentation of intestinal strongyloidiasis. Jpn J Infect Dis 2008; 61: 5-8.

14. Fouladvand M, Barazesh A, Tahmasebi R. Seroepidemiological study of strongyloidiasis in patients taking immunosuppressive drugs in Bushehr, Iran, 2012. J Mazandaran Univ Med Sci 2017; 27: 187-91.

15. Barazesh A, Fouladvand M, Tahmasebi R, Heydari A, Fallahi J. The prevalence of intestinal parasites in hemodialysis patients in Bushehr, Iran. Hemodial Int 2015; 19: 447-51.

16. Togeh GR, Keyhani M, Atharei A, Sadafei H. Prevalence of intestinal parasites in cancer patients undergoing chemotherapy. Tehran Uni Med J 2000; 58: 52-8.

17. Brayman KL, Stephanian E, Matas AJ, Schmidt W, Payne WD, Sutherland $\mathrm{DE}$, et al. Analysis of infectious complications occurring after solid-organ transplantation. Arch Surg 1992; 127: 38-47.

18. Athari A, Sadafi H, TokehGh.R. Intestinal parasites in immunocompromised patients in Tehran in 1998. J Zanjan Uni Med Sci 2000; 30: 61-8.(4 ile 18 AYNI)

19. Keiser PB, Nutman TB. Strongyloides stercoralis in the Immunocompromised Population. Clin Microbiol Rev 2004; 17: 208-17.

20. Vasquez-Rios G, Pineda-Reyes R, Ruiz EF, Terashima A, Mejia F. Strongyloides stercoralis infection after the use of emergency corticosteroids: a case report on hyperinfection syndrome. J Med Case Rep 2019; 13: 121.

21. Salehi Sangani G, Mirjalali H, Farnia S, Rezaeian M. Prevalence of Intestinal Coccidial Infections among Different Groups of Immunocompromised Patients. Iran J Parasitol 2016; 11: 332-8.

22. Fouladvand M, Barazesh A, Naeimi B, Najafi A. Frequency of Cryptosporidium infection and related factors under five year's old children hospitalized with gastroenteritis. African J Microbiol Res 2012; 6: 4102-6. 